\title{
KOMBINASI MODEL PEMBELAJARAN KOOPERATIF TIPE JIGSAW II DAN NUMBERED HEAD TOGETHER PADA HASIL BELAJAR MATEMATIKA SISWA SMA NEGERI 3 SORONG
}

\author{
Faisal Eka Mahendra \\ Pendidikan Matematika, Universitas Muhammadiyah Sorong \\ Email: faisalekamahendra132@gmail.com
}

\begin{abstract}
[Effectiveness of Cooperative Learning Types Jigsaw II and NHT Combination for Mathematic Outcomes on Tenth Science Grade Student of SMA N 3] This research aim to see the differences between conventional learning and cooperative learning types jigsaw II and NHT combination. In this research, sampling technique using is simple random sampling in tenth science five as an experiment class (method implemented) and tenth science four as an control class (conventional class). The datas about experiment, control class, and experiment try out collecting from documentation method. The test will be given after implementation has done in experiment class and will be given the same test in control class without the implementation. Each RPP signification in t-test are: first RPP is $0,42<0,05$, second RPP is $0,003<0,05$, the third is $0,000<0,05$. The difference will be seen ini t_count $>t$ table, they are 2,083 > 2,004; 3,084 > 2,004; and 6,982 > 2,004. This shows that t_count $>$ t_table, so Ha being accepted. That means, the average of student's outcomes of experiment class which teachs by jigsaw II and NHT combination really has the difference from conttol class. In this research the average of experiment class is 66,24 when control class is 43,73 . It clearly shows that the average of experiment class higher than control class.
\end{abstract}

Keywords: author guidelines; Teknik journal; article template

\section{PENDAHULUAN}

Pada umumnya dalam pembelajaran matematika siswa lebih banyak dituntut untuk mempelajari konsep-konsep. Cara pembelajaran seperti itu menyebabkan siswa pada umumnya hanya mengenal banyak peristilahan matematika secara hafalan tanpa makna. Di lain pihak, banyaknya konsep-konsep yang perlu dipelajari siswa, menyebabkan munculnya kejenuhan siswa belajar matematika secara hafalan. Seiring dengan perkembangan jaman, maka pembelajaran matematika dewasa ini mengalami pergeseran menyusul bertambahnya tuntutan dan tantangan yang harus dihadapi memasuki era persaingan global abad ke-21. Hal ini menyebabkan pembelajaran matematika di Indonesia perlu diubah agar dapat membekali setiap siswa dengan kemampuan berpikir. 
Guru memiliki peranan penting dalam menciptakan suasana atau proses belajar yang menyenangkan. Sebab pada umumnya guru yang memegang kendali dalam proses belajar di kelas. Proses pembelajaran dapat berlangsung dengan baik dengan campur tangan seorang guru. Seorang guru harus mampu dan menguasai cara penyampaian materi pembelajaran dengan menggunakan media, metode, dan model yang tepat dalam proses pembelajaran. Apabila seorang guru dalam melakukan persiapan pembelajaran sudah optimal, maka dalam proses pembelajaran diharapkan hasilnya juga memuaskan. Selain itu, guru harus dapat mengatasi kendala-kendala yang dihadapi oleh siswa.

Banyak kendala yang dihadapi oleh siswa diantaranya adalah masalah-masalah intelektual serta perilaku siswa itu sendiri. Seperti halnya dengan yang dijumpai pada SMA Negeri 3 Sorong. Peneliti memilih sekolah ini karena predikat akreditasi sekolah yang baik. Namun tingkat keberhasilan akademik siswa belum maksimal. Berdasarkan observasi dan wawancara yang dilakukan di SMA Negeri 3 Sorong ternyata sebagian besar siswa masih mengalami kesulitan dalam memahami materi matematika. Hal ini disebabkan karena kurangnya keingintahuan siswa dalam mempelajari matematika, sehingga sebagian besar siswa tidak aktif dalam proses belajar matematika. Kurang fokusnya pada saat guru menerangkan menyebabkan siswa tidak berkonsentrasi dan lebih banyak berdiskusi dengan teman lainnya sehingga berdiskusi dengan teman lainnya lebih disukai daripada pelajaran matematika. Tanggung jawab siswa terhadap tugas yang diberikan guru tidak sepenuhnya dilaksanakan secara langsung karena kurangnya pemahaman dalam materi yang disampaikan. Selain itu, anggapan bahwa matematika itu sulit masih menjadi hal yang dirasakan oleh siswa, sehingga kemampuan siswa dalam pembelajaran matematika rendah.

Upaya yang dapat dilakukan untuk mengatasi permasalahan-permasalahan di atas yaitu dengan menerapkan model pembelajaran yang mampu mengembangkan aktivitas siswa dalam pembelajaran sehingga dapat mengembangkan kemampuan siswa. Salah satunya yaitu penerapan kombinasi model pembelajaran Jigsaw II dan Numbered Head Together (NHT).

Kombinasi model pembelajaran Jigsaw II dan NHT mengajak siswa untuk bertanggung jawab dalam menyelesaikan tugas, meningkatkan ketrampilan siswa dalam 
berkomunikasi antar anggota dalam satu kelompok untuk mengutarakan pendapat, melatih kemampuan siswa untuk bekerjasama dalam suasana gotong royong sehingga siswa akan lebih termotivasi dalam belajar. Berdasarkan uraian di atas maka peneliti merasa bahwa kombinasi model pembelajaran Jigsaw II dan NHT dapat mendorong keingintahuan siswa dalam pembelajaran matematika, sehingga hasil belajar siswa dalam pelajaran matematika dapat meningkat.

1. Rumusan Masalah

Berdasarkan latar belakang masalah yang dipaparkan di atas, maka rumusan masalah dalam penelitian ini adalah: "Apakah terdapat perbedaan hasil belajar antara model pembelajaran konvensional dengan kombinasi model pembelajaran Jigsaw II dan NHT?"

\section{METODE PENELITIAN}

1. Desain Penelitian

Penelitian ini dilakukan pada dua kelas yang memiliki kemampuan setara, satu kelompok kontrol dan satu kelompok eksperimen, yang diajarkan oleh satu orang guru. Dalam desain ini, kedua kelompok diberi tes awal (pretest) dengan tes yang sama. Selanjutnya, pada kelas ekperimen menggunakan kombinasi model pembelajaran Jigsaw II dan NHT sedangkan pada kelas kontrol menggunakan pembelajaran konvensional. Pretest dan posttest diberikan pada setiap saat awal dan akhir proses pembelajaran di kelas kontrol maupun kelas ekperimen. Hasil kedua tes pada tiap kelas (kelas kontrol dan kelas eksperimen) dibandingkan (diuji perbedaannya)

2. Subyek (Populasi dan Sampel)

Populasi penelitian ini adalah seluruh kelas X IPA pada SMA negeri 3 Kota Sorong yang terdiri dari 7 kelas.. Sampel pada penelitian ini adalah kelas X IPA 4 dan X IPA 5.

3. Teknik Sampling

Dalam penelitian ini, teknik sampling yang digunakan adalah simple random sampling yaitu pengambilan sampel secara acak tanpa memperhatikan strata yang ada. Simple random sampling memberikan hak yang sama bagi anggota populasi untuk dipilih menjadi sampel. 


\section{Instrumen Penelitian}

\subsection{Dokumentasi}

Metode ini digunakan untuk memperoleh daftar nama peserta didik yang termasuk dalam populasi dan sampel penelitian, serta untuk memperoleh data nilai peserta didik pada mata pelajaran matematika. Data tersebut digunakan untuk membentuk kelompok asal pada model pembelajaran Jigsaw.

\subsection{Tes}

Teknik pengumpulan data yang dilakukan pada penelitian ini adalah dengan menggunakan pretest dan posttest. Tes dilaksanakan dua kali, yaitu sebelum dan sesudah siswa diberi perlakuan.

\section{Teknik Analisis Data}

\subsection{Analisis Uji Coba Instrumen}

Sebelum soal tes digunakan mengukur kemampuan pada kelas eksperimen dan kelas kontrol, terlebih dahulu soal tes diuji cobakan. Uji coba dilakukan untuk mengetahui validitas, reliabilitas dari tiap-tiap butir soal

\subsection{Analisis Prasyarat}

Analisis prasyarat meliputi N-Gain Ternormalitas, uji normalitas dan homogenitas. Apabila data memenuhi ketiga kriteriat ersebut maka data dilanjutkan ke analisis data berikutnya yaitu analisis hipotesis.

\subsection{Analisis Data Akhir}

Uji hipotesis untuk menguji hipotesis komparatif dua sampel yang berkorelasi adalah uji-t (uji beda).

\section{Deskripsi dan Hasil Penelitian}

Data hasil penelitian yang diperoleh dianalisis untuk menjawab masalah penelitian. Analisis dilakukan terhadap data sebelum penerapan model pembelajaran, pada saat penerapan model pembelajaran, dan sesudah penerapan model pembelajaran, sehingga data yang diperoleh terdiri dari nilai pretest dan posttest. Hasil analisis data akan ditampilkan dalam bentuk tabel. Pengolahan data yang diperoleh dilakukan secara otomatis dengan menggunakan SPSS 17.0. Analisis hasil penelitian dimulai dengan melakukan uji validitas 
dan reliabilitas instrumen soal RPP 1, soal RPP 2, dan soal RPP 3. Uji validitas dilakukan dengan teknik. Reliabilitas suatu instrumen dapat dilihat dari angka atau nilai Croncbach's Alpha. Apabila nilai Croncbach's Alpha lebih besar dari $\mathrm{r} \geq 0,06$ tabel maka instrumen tersebut dinyatakan reliabel.

6.1. Validitas dan Reliabel

a. Analisis Validitas dan Reliabilitas Uji Coba Pretest dan Posttest RPP I

\begin{tabular}{ccccc} 
No. Soal & Hasil Uji Valid & Hasil Uji Reliabilitas & Keterangan & Keputusan \\
\hline 1 & 0.676 & 0.622 & Valid/Reliabel & Dipakai \\
\hline 2 & 0.409 & 0.322 & Valid/Reliabel & Dipakai \\
\hline 3 & 0.531 & 0.481 & Valid/Reliabel & Dipakai \\
\hline 4 & 0.676 & 0.622 & Valid/Reliabel & Dipakai \\
\hline 5 & 0.686 & 0.623 & Valid/Reliabel & Dipakai \\
\hline 6 & 0.445 & 0.331 & Valid/Reliabel & Dipakai \\
\hline 7 & 0.170 & 0.123 & Tidak Valid/Reliabel & Dibuang \\
\hline 8 & 0.510 & 0.409 & Valid/Reliabel & Dipakai \\
\hline 9 & 0.299 & 0.206 & Tidak Valid/Reliabel & Dibuang \\
\hline 10 & 0.584 & 0.493 & Valid/Reliabel & Dipakai \\
\hline
\end{tabular}

Tabel 4.1 Hasil Uji Validitas dan Reliabilitas RPP 1

Sumber :output SPSS $17.0: 2014$

Dari hasil analisa menggunakan software SPSS 17.0 dari 10 soal pretest dan posttest yang diuji cobakan, pada RPP 1 diperoleh 8 soal yang valid dan reliabel, yaitu soal nomor 1, 2, 3, 4, 5, 6, 8, 10. Sedangkan soal dengan nomor 7 dan 9 tidak digunakan dalam penelitian karena tidak valid. Hal ini dapat dilihat pada tabel 4.1. 
b. Analisis Validitas dan Reliabilitas Uji Coba Pretest dan Posttest RPP II

Tabel 4.2 Hasil Uji Validitas dan Reliabilitas RPP 2

\begin{tabular}{ccccc} 
No. Soal & $\begin{array}{c}\text { Hasil Uji } \\
\text { Valid }\end{array}$ & $\begin{array}{c}\text { Hasil Uji } \\
\text { Reliabilitas }\end{array}$ & Keterangan & Keputusan \\
\hline 1 & 0.407 & 0.348 & Valid/Reliabel & Dipakai \\
\hline 2 & 0.682 & 0.618 & Valid/Reliabel & Dipakai \\
\hline 3 & 0.569 & 0.492 & Valid/Reliabel & Dipakai \\
\hline 4 & 0.513 & 0.434 & Valid/Reliabel & Dipakai \\
\hline 5 & 0.509 & 0.418 & Valid/Reliabel & Dipakai \\
\hline 6 & 0.641 & 0.592 & Valid/Reliabel & Dipakai \\
\hline 7 & 0.557 & 0.472 & Valid/Reliabel & Dipakai \\
\hline 8 & 0.628 & 0.557 & Valid/Reliabel & Dipakai \\
\hline 9 & 0.650 & 0.581 & Valid/Reliabel & Dipakai \\
\hline 10 & -0.149 & -0.250 & Tidak Valid/tidak Reliabel & Dibuang \\
\hline
\end{tabular}

Sumber :output SPSS $17.0: 2014$

Pada RPP 2 dari 10 soal pretest dan posttest yang diujicobakan, diperoleh 9 soal yang valid dan reliabel, yaitu soal nomor 1, 2, 3, 4, 5, 6, 7, 8, 9. Sedangkan soal dengan nomor 10 tidak dipakai untuk penelitian karena tidak valid dan tidak reliabel. Hal ini dapat dilihat pada tabel 4.2.

c. Analisis Validitas dan Reliabilitas Uji Coba Pretest dan Posttest RPP III

Pada RPP 3 dari 10 soal pretest dan posttest yang diujicobakan, diperoleh 9 soal yang valid dan reliabel, yaitu soal nomor 1, 2, 3, 5, 6, 7, 8, 9,10. Sedangkan soal dengan nomor 4 tidak dipakai untuk penelitian karena tidak valid dan tidak reliabel. Hal ini dapat dilihat pada tabel 4.3.

Tabel 4.3 Hasil Uji Validitas dan Reliabilitas RPP 3

No. Hasil Uji Hasil Uji $\quad$ Keterangan $\quad$ Keputusan




\begin{tabular}{ccccc}
\hline Soal & Valid & Reliabilitas & & \\
\hline 1 & 448 & 371 & Valid/Reliabel & Dipakai \\
\hline 2 & 602 & 531 & Valid/Reliabel & Dipakai \\
\hline 3 & 723 & 672 & Valid/Reliabel & Dipakai \\
\hline 4 & 0 & 0 & Tidak Valid/tidak Reliabel & Dibuang \\
\hline 5 & 0.420 & 337 & Valid/Reliabel & Dipakai \\
\hline 6 & 0.655 & 586 & Valid/Reliabel & Dipakai \\
\hline 7 & 0.657 & 591 & Valid/Reliabel & Dipakai \\
\hline 8 & 0.494 & 451 & Valid/Reliabel & Dipakai \\
\hline 9 & 0.626 & 553 & Valid/Reliabel & Dipakai \\
\hline 10 & 0.541 & 463 & Valid/Reliabel & Dipakai \\
\hline
\end{tabular}

Sumber :output SPSS $17.0: 2014$

\section{N-Gain}

$\mathrm{N}$-gain dalam penelitian ini adalah nilai peningkatan hasil belajar siswa baik untuk kelas kontrol maupun eksperimen. Hasilnya dianalisis untuk mengetahui penguasaan materi pada pokok bahasan pangkat, akar dan logaritma. Jumlah soal yang digunakan adalah 8 butir soal pilihan ganda untuk RPP 1, 9 butir soal pilihan ganda untuk RPP 2 dan 9 butir soal pilihan ganda untuk RPP 3. Perolehan hasil N-Gain pada kelas kontrol maupun eksperimen pada masing-masing RPP dapat dilihat pada tabel Tabel sebagai berikut: 
Tabel 4.4 Hasil Perolehan Rata-Rata N-Gain untuk Setiap RPP

\begin{tabular}{|c|c|c|c|c|}
\hline \multicolumn{5}{|c|}{ Kategori } \\
\hline \multicolumn{2}{|r|}{ RPP 1} & \multicolumn{2}{|r|}{ RPP 2} & RPP 3 \\
\hline NG1 & & NG2 & & NG3 \\
\hline Kontro & NG1 Eksperimen & Kontr & NG2 Eksperimen & KontrNG3 Eksperimen \\
\hline 1 & & ol & & ol \\
\hline 0,2 & 0,3 & 0,2 & 0,6 & 0,6 \\
\hline
\end{tabular}

Sumber :output SPSS $17.0: 2014$

Berdasarkan Tabel 4.4 di atas menunjukan bahwa rata-rata N-Gain pada RPP 1, RPP 2 dan RPP 3 untuk kelas kontrol masing-masing adalah 0,2;0,3;0,2. Nilai ini berada pada N-Gain dengan kategori rendah. Sedangkan rata-rata N-Gain untuk kelas ekperimen pada RPP 1, RPP 2 dan RPP 3 masing-masing adalah 0,4;0,6;0,6. Nilai ini berada pada N-Gain dengan kategori sedang. N-gain pada kelas eksperimen menunjukkan hasil yang lebih baik daripada N-gain pada kelas kontrol. Hal ini menunjukkan bahwa hasil belajar siswa dengan menggunakan model pembelajaran kooperatif tipe Jigsaw II dan NHT lebih baik daripada hasil belajar siswa dengan menggunakan model pembelajaran konvensional.

\section{Uji Normalitas}

Uji normalitas data digunakan untuk mengetahui apakah data yang digunakan berdistribusi secara normal atau tidak. Sebuah data akan dinyatakan berdistribusi normal jika memiliki nilai signifikansi > 0,05 pada taraf kepercayaan 95\%. Setelah dilakukan pengolahan data menggunakan SPSS 17.0, diperoleh tampilan output seperti pada tabel berikut: 
Tabel 4.5 Hasil Uji Normalitas N-Gain tiap RPP kelas Konrol dan Eksperimen One-Sample Kolmogorov-Smirnov Test

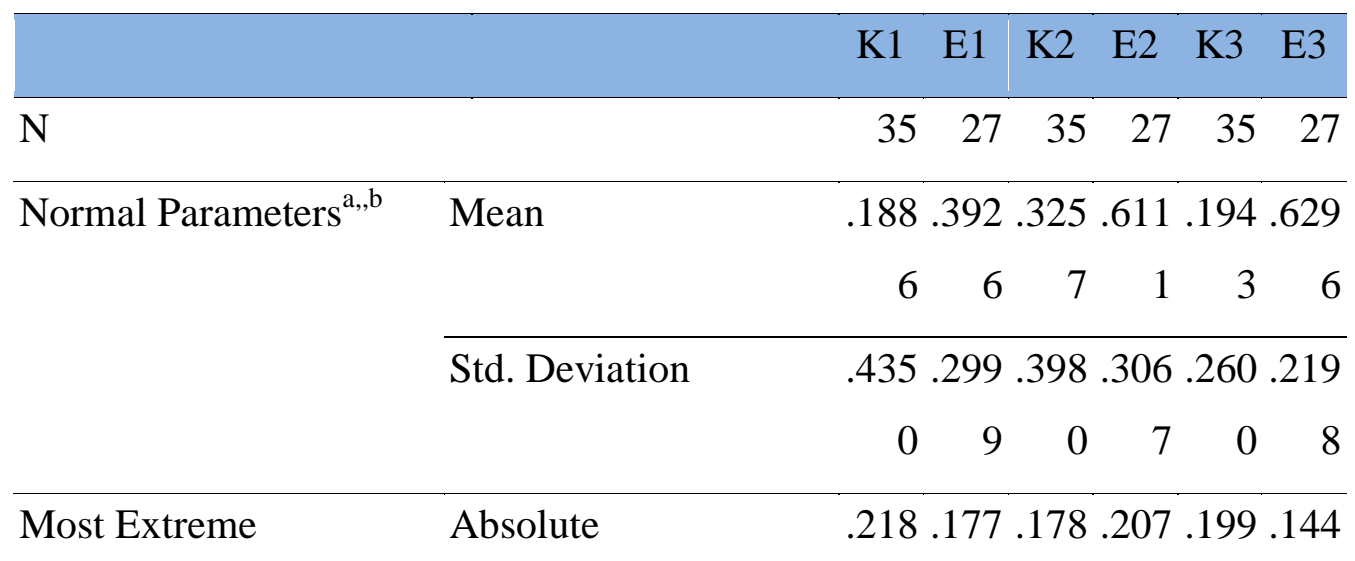

Differences

\begin{tabular}{|c|c|}
\hline Positive & 1153.177. 154. 154. 154. \\
\hline
\end{tabular}

.218 .120 .178 .207 .166 .144

\begin{tabular}{|c|c|}
\hline \multirow[t]{2}{*}{ Kolmogorov-Smirnov Z } & $\begin{array}{lllll}1.29 & 919 & 1.05 & 1.07 & 1.17\end{array}$ \\
\hline & 9 \\
\hline
\end{tabular}

Asymp. Sig. (2-tailed)

.072 .367 .217 .199 .124 .629
a. Test distribution is Normal.
b. Calculated from data.
Sumber : output SPSS $17.0: 2014$

\section{Uji Homogenitas}

Setelah diketahui bahwa nilai N-Gain pada kelas kontrol dan kelas eksperimen berdistribusi normal maka dilanjutkan dengan uji homogenitas. Hasil perhitungan uji homogenitas nilai N-Gain pada kelas kontrol dan kelas eksperimen disajikan dalam tabel 4.6 berikut. 
Tabel 4.6 Uji homogen RPP 1, RPP 2 dan RPP

\begin{tabular}{ccl}
\hline Variabel & Hasil signifikan hitung & Keputusan \\
\hline RPP 1 & $0_{x} 129>0,05$ & Homogen \\
\hline RPP 2 & $0_{x} 473>0,05$ & Homogen \\
\hline RPP 3 & $0_{x} 989>0,05$ & Homogen \\
\hline
\end{tabular}

Sumber :output SPSS $17.0: 2014$

Pada tabel hasil uji homogenitas RPP 1 kelas kontrol dan kelas eksperimen di atas, diperoleh nilai Sig. 0,129 (>0,05). Pada RPP 2 diperoleh nilai Sig. 0,473(>0,05). Pada RPP 3 diperoleh nilai Sig. 0,989 $(>0,05)$. Sehingga dapat disimpulkan bahwa RPP 1, RPP 2, RPP 3 pada kelas kontrol dan eksperimen homogen.

\section{Uji T}

Setelah melakukan uji normalitas dan homogenitas yang menunjukkan bahwa data berdistribusi normal dan homogen, maka analisis data dapat dilanjutkan ke tahap berikutnya yaitu uji t. Uji t yang digunakan adalah uji t sampel bebas. Uji ini dilakukan untuk mengetahui perbedaan hasil belajar antara kelas kontrol dan kelas eksperimen.

Hipotesis dalam uji t adalah sebagai berikut:

Ho: Tidak terdapat perbedaan hasil belajar matematika antara kelas yang diberikan model pembelajaran konvensional dan kelas yang diberikan kombinasi model pembelajaran Jigsaw II dan NHT.

Ha: Terdapat perbedaan hasil belajar matematika antara kelas yang diberikan model pembelajaran konvensional dan kelas yang diberikan kombinasi model pembelajaran Jigsaw II dan NHT.

Apabila dirumuskan ke dalam hipotesis statistik adalah sebagai berikut:

$$
\begin{aligned}
& H_{0}: \mu_{1}=\mu_{2} \\
& H_{\text {बa }}: \mu_{1} \neq \mu_{2}
\end{aligned}
$$


Kriteria pengambilan keputusannya yaitu:

a. Jika nilai signifikansi lebih kecil dari 0,05 maka $H_{0}$ ditolak.

b. Jika nilai signifikansi lebih besar dari 0,05 maka $H_{0}$ diterima.

Setelah dilakukan pengolahan data menggunakan SPSS 17.0, diperoleh hasil uji-t pada masing-masing RPP sebagai berikut:

Tabel 4.7 Uji T

\begin{tabular}{cccc}
\hline Variabel & Signifikan hitung & t hitung & Keputusan \\
\cline { 1 - 3 } RPP 1 & $0,042<0,05$ & $2,083>2,004$ & \multirow{2}{*}{$\mathrm{H}_{\mathrm{a}}$} \\
\cline { 1 - 3 } RPP 2 & $0,003<0,05$ & $3,084>2,004$ & diterima \\
\cline { 1 - 3 } RPP 3 & $0,000<0,05$ & $6,982>2,004$ & \\
\hline
\end{tabular}

Sumber :output SPSS $17.0: 2014$

\section{Kesimpulan}

Berdasarkan permasalahan dari peneliti dan hasil analisis data sebagaimana yang telah dikemukakan pada bab sebelumnya serta merujuk pada judul penelitian mengenai efektivitas kombinasi model pembelajaran kooperatif tipe Jigsaw II dengan NHT pada hasil belajar matematika siswa kelas X SMA Negeri 3 Kota Sorong maka dapat ditarik kesimpulan sebagai berikut:

1. Terdapat perbedaan hasil belajar antara siswa yang diterapkan kombinasi model pembelajaran Jigsaw II dan NHT (kelas eksperimen) dengan siswa yang diterapkan model pembelajaran konvensional (kelas kontrol) pada materi pangkat, akar dan logaritma di kelas X SMA Negeri 3 Kota Sorong berdasarkan hasil taraf signifikansi $i_{\text {hitung }}<0,05$

2. Hasil belajar peserta didik yang menggunakan kombinasi model pembelajaran Jigsaw II dan $N H T$ lebih baik dari pada peserta didik yang menggunakan model pembelajaran Konvensional. Hal ini terbukti dengan nilai rata-rata kelas eksperimen dan kontrol secara berturut-turut adalah dan 64,24 dan 43,74 serta hasil uji t yang menunjukkan $t_{\text {hitung }}$ $>t_{\text {tabel }}$ yaitu 3,083>2,004; ; dan 6,982>2,004, sehingga Ha diterima 


\section{Daftar Pustaka}

Arikunto, Suharsimi. 2006. Prosedur Penelitian Suatu Pendekatan Praktik.Jakarta: Rineka Cipta.

Agnes Stevine Luhukay, 2013. Perbedaan Penggunaan Pendekatan Kontekstual dengan Gaya Belajar VAK (Visual-Auditory-Khinesthetic) dalam Meningkatkan Pemahaman Konsep Matematika dan Melatih Logika Berpikir Siswa Kelas VIII Mts. Al-Gebra Kota Sorong. Skripsi. Sorong. FKIP. UMS.

Dananjaya, Utomo. 2010. Media Pembelajaran Aktif. Bandung: Nuansa.

Diah Savitri. 2014. Penerapan Pendekatan Pembelajaran Kontekstual Berbasis Lingkungan Terhadap Peningkatan Penguasaan Konsep dan Motivasi Belajar IPA. Tesis. Program Studi Magister Pendidikan IPA Program Pascasarjana Universitas Cenderawasih Jayapura.

Hamalik, Oemar. 2005. Proses Belajar Mengajar. Jakarta: Bumi Aksara.

Kamus Pusat Bahasa, Kamus Besar Bahasa Indonesia, Jakarta: Balai Pustaka, 2001.

Khomsatun. 2013. Efektifitas Model Pembelajaran Jigsaw II dengan Media CD Interaktif dan Macromedia Flash 8 Terhadap Hasil Belajar Siswa pada Materi Segi Empat Kelas VII SMP. Skripsi. Prodi Pendidikan Matematika Fakultas Matematika dan IPA IKIP PGRI Semarang.

Lie, Anita 2002. Cooperatif Learning Mempraktikkan Cooperatif Learning di Ruang-ruang Kelas, Jakarta: PT. Gramedia.

Ngalimun, 2014.Stratgi dan Model Pembelajaran. Yogyakarta: Aswaja Pressindo.

Ni'mah Maulidah. 2009. Efektivitas Model Pembelajaran Cooperative Learning Tipe Jigsaw dengan Menggunakan Alat Peraga terhadap Hasil Belajar Peserta Didik pada Materi Bangun Ruang Sisi Lengkung di MTs Miftahul Falah Demak Tahun Pelajaran 2008/2009. Skripsi. Semarang: Program Strata I Jurusan Tadris Matematika Fakultas Tarbiyah IAIN Walisongo.

Oktari Adin Widati, 2012. Meningkatkan Hasil Belajar Matematika Siswa Melalui Metode Aritmetika Cepat Pada Siswa Kelas VIIA SMP Negeri 8 Sorong. Skripsi. Sorong. FKIP. UMS.

Sani, R.A. 2013. Inovasi Pembelajaran. Jakarta: Bumi Askara.

Sitorus Herta Delima, dkk. Efektivitas Model Pembelajaran Tipe Numbered Head Together (NHT) Pada Mata Pelajaran Teknologi Informasi Dan Komunikasi (TIK) Terhadap Hasil Belajar Siswa

Slavin, R.E. 2005. Cooperative Learning Teori, Riset dan Praktik. Bandung: Nusa Media.

Sudjana, Nana. 2011. Penilaian Hasil Proses Belajar Mengajar,Bandung : PT. Remaja Rosdakarya.

Sugiarto, et.al.,Teknik Sampling, (Jakarta: PT Gramedia Pustaka Utama, 2003), Cet. 3

Sugiyono. 1999. Statistika untuk Penelitian. Bandung: CV ALFABETA

Sugiyono. 2008. Metode Penelitian Pendidikan Pendekatan Kuantitatif, Kualitatif, dan R\&D. Bandung: Alfabeta. 
Sundari. 2013. Meningkatkan Motivasi Dan Hasil Belajar Siswa Dalam Pembelajaran Matematika Melalui Pendekatan Savi Pada Siswa Kelas V.A Sdit Al-Izzah Sorong. Skripsi. Sorong. FKIP. UMS.

Syah, Muhibbin. 2008. Psikologi Pendidikan dengan Pendekatan Baru. Bandung: Remaja Rosdakarya.

Trianto. 2007. Model-model Pmbelajaran Inovatif Berorientasi Kontruktivistik. Jakarta: Prestasi Pustaka.

Widiyanto. 2014. Pengaruh Perhatian Orang Tua dan Penguasaan Materi Prasyarat Terhadap Prestasi Belajar Matematika Peserta Didik SMA N 4 Kota Sorong. Tesis. Program Studi Magister Pendidikan IPA Program Pascasarjana Universitas Cenderawasih Jayapura.

Wikipedia. http://id.m.wikipedia.org/wiki/Matematika (Online) diakses pada 20 Februari 2014 